\title{
Cytotoxic Chemical Constituents from the Roots of Cimicifuga foetida
}

Yin Nian, ${ }^{\dagger, \ddagger}$ Yan-Li Zhang, ${ }^{\S}$ Jian-Chao Chen, ${ }^{\dagger}$ Lu Lu, ${ }^{\dagger, \ddagger}$ Chen Qing ${ }^{*, \S}$ and Ming-Hua Qiu, ${ }^{*, \dagger}$

State Key Laboratory of Phytochemistry and Plant Resources in West China, Kunming Institute of Botany, Chinese

Academy of Sciences, Kunming 650204 P. R. China,

Graduate School of the Chinese Academy of Sciences, Beijing 100049, P. R. China

Yunnan Key Laboratory of Pharmacology for Natural Products Research, Kunming Medical College, Kunming

650031, P. R. China

*To whom correspondence should be addressed. Tel: 86-871-522-3257. Fax: 86-871-522-3255. E-mail:

mhchiu@mail.kib.ac.cn

${ }^{\dagger}$ Kunming Institute of Botany

${ }^{\ddagger}$ Graduate School of the Chinese Academy of Sciences

${ }^{\S}$ Kunming Medical College 


\section{Cell lines and culture}

The human hepatoma cell line HepG2, human breast carcinoma cell line MCF7, human colon carcinoma cell line HT29 and human gastric carcinoma cell line MKN28 were obtained from the American Type Culture Collection

(ATCC). All cell lines were grown in RPMI-1640 medium (GIBCO) supplemented with 10\% heat-inactivated bovine serum, 2nM L-glutamine, $10^{5} \mathrm{IU} / \mathrm{L}$ penicillin, $100 \mathrm{mg} / \mathrm{L}$ streptomycin and 10mM HEPES pH 7.4. Cells were kept at $37^{\circ} \mathrm{C}$ in a humidified $5 \% \mathrm{CO}_{2}$ incubator.

\section{Cell growth inhibition assay}

Growth inhibition of compounds 1-7 on human tumor cells HepG2, MCF7, HT29 and MKN28 was measured by microculture tetrazolium (MTT) assay [1], [2] with minor modification [3]. Briefly, tumor cells were seeded into 96-well microculture plates and allowed to adhere for $24 \mathrm{~h}$ before drug addition. The cell densities were selected based on the results of preliminary tests to maintain the control cells in an exponential phase of growth during the period of the experiment and to obtain a linear relationship between the optical density and the number of viable cells. Each tumor cell line was exposed to compounds 1-7 at 0.01, 0.1, 1, 10 and $100 \mu \mathrm{g} / \mathrm{ml}$ concentrations for $72 \mathrm{~h}$ and each concentration was tested in triplicate. At the end of exposure, $20 \mu \mathrm{l}$ of $5 \mathrm{~g} / \mathrm{L}$ MTT [3-(4, 5-dimethylthiazol-2yl)-2, 5-diphenyl tetrazolium bromide, Sigma Chemical Co.] was added to each well and the plates were incubated for $4 \mathrm{~h}$ at $37^{\circ} \mathrm{C}$, then “triplex solution (10\% SDS - 5\% isobutanol - $0.012 \mathrm{M} \mathrm{HCl)”} \mathrm{was}$ added and the plates were incubated for $12-20 \mathrm{~h}$ at $37^{\circ} \mathrm{C}$. The optical density (OD) was read on a plate reader at a wavelength of $570 \mathrm{~nm}$. Media and DMSO control wells, in which albaconol was absent, were included in all the experiments in order to eliminate the influence of DMSO. The inhibitory rate of cell proliferation was calculated by the following formula: Growth inhibition $(\%)=\mathrm{OD}_{\text {control }}-\mathrm{OD}_{\text {treated }} / \mathrm{OD}_{\text {control }} \times 100 \%$. The cytotoxicity of 
compounds 1-7 on tumor cells was expressed as $\mathrm{IC}_{50}$ values (the drug concentration reducing by $50 \%$ the absorbance in treated cells, with respect to untreated cells) that was calculated by LOGIT method.

\section{References}

(1) Mosmman T. J. Immunol. Meth. 1983, 65, 55-63.

(2) Alley M.C.; Scudiero D.A.; Monks A.; Hursey M.L. Cancer Res. 1988, 48, 589-601.

(3) Zhou J.J.; Yue X.F.; Han J.X.; Yang W.Y. Chin. J. Pharm. 1993, 24, 455-7. 